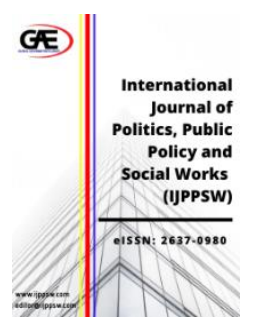

\author{
International Journal of Politics, Publics \\ Policy and Social Works (IJPPSW) \\ Journal Website: http://ijppsw.com/ \\ eISSN: 2637-0980
}

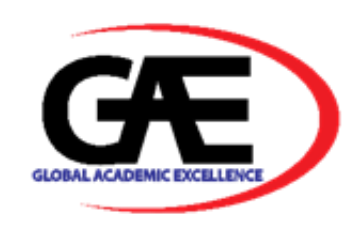

\title{
THE IMPACT OF FISCAL POLICY ON GDP PER CAPITA: EVIDENCE FROM MALAYSIA
}

\author{
Nor Asmat Ismail ${ }^{1 *}$, Abdallah El Moctar El Houssein ${ }^{2}$ \\ 1 School of Social Sciences, Universiti Sains Malaysia, Malaysia \\ Email: norasmat@usm.my \\ 2 School of Social Sciences, Universiti Sains Malaysia, Malaysia \\ Email: abdallah93@student.usm.my \\ * Corresponding Author
}

\section{Article Info: \\ Article history: \\ Received date:29.05.2020 \\ Revised date: 05.06.2020 \\ Accepted date: 12.06 .2020 \\ Published date: 15.06.2020 \\ To cite this document: \\ Ismail. N. A., \& Houssein, A. E. M. E. (2020). The Impact of Fiscal Policy on GDP Per Capita: Evidence from Malaysia. International Journal of Politics, Publics Policy and Social Works, 2 (5), 14-25.}

DOI: $10.35631 /$ IJPPSW.25002.

\begin{abstract}
:
This study investigated the relationship between income per capita and government spending in Malaysia using annual data spanning from 1980-2018. Auto-regressive distributed lag (ARDL) and VAR-differenced model (VECM) was employed to examine the relationship between income per capita, government consumption, and government expenditure on education. Inflation is used as a control variable in the model. The result concluded that government consumption, government expenditure in education, and inflation have a unidirectional short-run causal effect on income per capita. In the long run, income per capita has a negative relationship with government consumption spending, while has a positive relationship with government expenditure in education. Government expenditure in education is crucially important in Malaysia and it should be continued to give more opportunities for Malaysians to get a better education and as a result, get a better job and improve the standard of living.
\end{abstract}

Keywords:

GDP Per Capita, Government Consumption, Education, Cointegration

\section{Introduction}

The Malaysian economy was performing well for the last few years responding to a strong domestic demand mostly represented by the increase in investment and consumption, the official statistics reports a strong performance in real GDP, growth was measured to be $5.6 \%$ in the first quarter of last year then followed by $5.8 \%$ and $6.2 \%$ in the second and third, mostly in manufacturing industry verified by the improving record of industrial production index (IPI), as well as exports which grew simultaneously. 
Growth in domestic demand when plotted shows 5\% growth from 0.2 percentage points year on year, both private consumption and private investment are in line with expectations of higher growth than previous year figures. Private consumption is expected to increase by $6.2 \%$. In 2017 private consumption recorded an increase of $6.6 \%$ in the first quarter, $7.1 \%$ in second, and $7.2 \%$ in the $3^{\text {rd }}$ quarter. Consumer spending is an indicator for a stable job market, contained inflation and a strengthening currency. Government announced several measures to boost disposable income in the 2018 Budget. More broadly economic activities performed well as a result of fiscal stimulus, especially for private investment and spending.

Malaysian economy is generally expected to improve as a result of growing trend in the world trade, the figures of 2017 in both exports and imports recorded growth rates of $20.7 \%$ and $21.6 \%$, most of imports where capital and semi-finished goods and the result is a total trade surplus of $89.9 \mathrm{~b}$ RM. The top five Malaysia's trading partners with which $55.7 \%$ of total trade value were delivered during the period January-November, 2017 were China, Singapore, the European Union, the USA and Japan.

The literature on fiscal policy until recently has been focused on macroeconomic importance of government spending as an adjustment tool and augmenting public debt and taxation policies in Malaysia. Originally the debates around effective fiscal design and policies has been going on since the great depression however as macroeconomic variables are not always steady in performance many governments around the world ensure maximum attention is given to fiscal stability. One example is the stability and growth agreement outlined in 1997 by the European member states who ratified it and agreed to jointly ensure the stability of their common fiscal regimes giving birth to what is now known as Economic and monetary union (EMU) in 1999.

In order for continuous growth to be maintained, more and more research on fiscal changes various effects must be empirically tested, when looking more deeply into fiscal policy research, three distinct schools of thought emerges: the first group of economists studied specific segments in relation to fiscal policy such as fiscal consolidation, second group of researchers were more concerned with stabilizing capabilities of fiscal policy tools such tax and transfer Regimes, and the ability to protect the economy against fiscal shocks and the changing effects of discretionary fiscal policies on macroeconomic variables, such studies has been replicated with econometric models (Blanchard \& Perotti, 1999) The present paper can be ascribed to the third school of macro research and focuses on the impact of fiscal policies on economic activities.

Its commonly believed in macroeconomic theory that an increase in government purchase would have an expansionary effect on output inspired by the work of Keynesian during early $20^{\text {th }}$ century, however the newer models were indifferent in regards to the effect on individual consumption as a vital segment in aggregate demand and its response is of utmost importance to the direction of the fiscal policy. The standard IS-LM model theory generally assumes that consumption will decline in response to an increasing government spending or as commonly referred to as government purchases, in contrast, the IS-LM model predicts that consumption should increase which will add to the effect of government spending on output, the different impact is constrained to the scenario in which consumer behaves in each case.

On a similar area, real business cycle theory (RBC) generally assumes a constant household spending which is restricted by a certain budget, more closely one can measure a big share of consumption by looking into income, in RBC if government spending increases it lowers the present value of after-tax income which invites negative wealth effects that induces a cut in 
consumption (Jordi, López-Salido, \& Vallés, 2007). The literature on consumption and income response to changes of fiscal policy is extensive, briefly one can say that an increase in (nonproductive) government expenditure which is financed by current or future taxes has a negative wealth effects reflected in lower levels of consumption, it's also apparent that it increases number of labor supplied at a certain wage which affect leads, in equilibrium, to a lower real wage, higher employment and higher output (Jordi, López-Salido, \& Vallés, 2007)

When talking about employment and real wage rates, negative wealth effects lead to a higher labor supply and an decreased real wage which is a general view in new classical Real business cycle model (RBC) that government consumption and how fiscal policy is adjusted "crowd out the private sector" and reduces real wage, despite the fact that such effect is tied to how those increases are financed, Previous studies has considered the fiscal shocks as exogenous factor, as in (Perotti, 2007) who identifies fiscal shocks as significant and surprising increases in government spending and delivered a coefficients that are generally in line with the RBC model as discussed by many other studies including Cavallo (2005).

The reality of many studies in this area is the importance of the introducing of government sector as a factor into the RBC model which has been emphasized as a good indication of model's ability to match the data, the standard real business cycle model cannot capture the average labor productivity and hours worked (Fatas \& Mihov, 1998). Government spending in this context can be a powerful explanatory variable; its power is derived from the fact that shifts in fiscal policy can alter labor supply and then turn correlation negative between hours and productivity, this negative correlation can offset the high positive co-movement between hours worked and labor productivity and hours driven by technology shocks. The data shows that while an increase in government spending occurs real wages decline while labor supply increases simultaneously the reason for that according to (Fatas \& Mihov, 1998) is due to the absorption of resources by the government, the rational economic reaction of private agents is to increase their workload and decrease their consumption.

A fiscal policy shock refers to sudden changes in the two major components of fiscal policy namely; government spending and government revenues. This study addresses the impact of shock in both sides on the consumption and eventually the aggregate output. Although a certain ambiguity can be sensed from the literature as to the nature of the shock for example; some have used shock when innovation was the right term, or instrument (Ramey V. ) views shocks as empirical counterparts to shocks of technology, monetary and fiscal policy, and in characteristics in order for them to be applicable for empirical evaluation they should exogenous in nature, uncorrelated with other shocks in order to ascertain the individual effects of the shock and lastly they should represent unanticipated movements in the exogenous variables or news about the future movements in them. The purpose of this paper is to test the effect of fiscal changes on the GDP per capita.

Furthermore, one challenge of fiscal policy shocks identification is the challenge of possible lags between announcement and implementation of changes in fiscal policy. For example; a reduction in tax is discussed within legislative bodies takes months to come into effect, the general public would expectedly have forward looking to adjust their consumption and other economic choices before the date of implementation. While the tax change effects take place, the surprise of a change in fiscal policy happens earlier to its actual date of implementation, therefore, to deal with this problem, the identification procedure is easily adapted by directly identifying a shock that have a lag between the policy announcement and the implementation. 
For example, if a government spending only rises in the fourth quarter of the year, this study should assume that the news shock occurs at the beginning of the year.

\section{Literature Review}

Throughout the Malaysian financial history since the independence onwards, the Central bank (Bank Negara) was highly engaged with the economy to achieve stability, by both activating expansionary policies to expand output or contractionary to protect against inflation pressure or control excessive liquidity in the market. Studying the shocks of Malaysian economy by 1997 crash, (Ibrahim, 2005) uses endogenous growth model and tested the impact of monetary changes on various sectors of the economy suggesting that for growth to be maintained, the empirical regularities are indicating three sectors manufacturing, construction and financial services. Inspiring the researcher to suggest that policymakers need to pay close attention to these sectors during fiscal changes.

On GDP per capita, the work of (Sharma \& Kautish, 2019) highlighted the effect of timelagged foreign aid and economic policy on income per capita across the region of South East Asia indicate that foreign aid has a negative relationship with GDP per capita, however the lagged version of itself is found to be insignificant, while the coefficient of the government expenditure relationship with GDP per capita has been found to be negative in the long run. Similarly in another relevant study by Cheong (2001) who examined the relationship between national income and government expenditure output between the Wagner's and Keynesian theory, testing the validity of Wagner's ${ }^{1}$ classical approach in particular within Malaysian context as opposed to Keynesian theory which treats government expenditure as a exogenous factor, indicate that there is no evidence for long run relationship between real per capita income and government expenditure over the period of 1960-1998. Furthermore, testing by standard granger tests, provides evidence of unidirectional causality from national income growth to government expenditure growth in Malaysia, hence wagner's theory is valid with Malaysian data in the short run. Furthermore, there was no possibility from his study to ensure that government expenditure as a policy instrument could be effectively used to encourage growth in the Malaysian economy.

The fiscal shocks is a highly debated subject in the literature of policy making, some researchers have used unrestricted or structured VAR-based analysis to estimate the impact of uncertainty shocks and recently a number of studies are using DSGE-based frameworks to trace the transmission of shocks through the economy (Mumtaz et al., 2018; Ibrahim, 2005). Mumtaz et al. (2018) uses Factor Augmented VAR to test the sectoral impact of uncertainty shocks in selected US states and found the effect to be heterogeneous, and that income declines larger in states that operate with high manufacturing, agriculture and construction industries which add merit to (Ibrahim, 2005) argument that these sectors are sensitive to uncertainty shocks and could be good drivers for growth.

The study of relationship between per capita income and output convergence is an important indicator for long-run policy forecasting. The work of Matsuki (2018) is aiming in that direction by adopting that convergence of output between two countries hold if the long run forecasts approach zero and uses covariate (ADF) unit root to enhance the estimation power of the tool, and investigate any convergence of series between one country to another, and furthermore to account for endogenous structural breaks in the series using the same method

\footnotetext{
${ }^{1}$ In brief, it's built on the assumption that government expenditure is an outcome for growth in national income, as GDP per capita increases, the share of public sector expenditure rises as well to meet the increasing protective and administrative functions of the state.

Copyright (C) GLOBAL ACADEMIC EXCELLENCE (M) SDN BHD - All rights reserved
} 
and noted significant growth factors regardless of the strong evidence of per capita income convergence in the Asian region and highlighted that its more evident in countries like Hong Kong, Singapore and Taiwan, while Malaysia, Indonesia and India are relatively lower.

The issue of fiscal changes pre-announcement is dealt with by Ricco (2015) employing a model that accounts for both the fiscal announcement of future changes (anticipation effect) and the expectations of individuals (informational flow) simultaneous to those fiscal changes and empirically examine the data by a novel study, he notes that potential misalignment between household information and econometrician statistics makes the estimated inferences problematic and hence information on fiscal shocks recovered by (VAR) based studies are inclusive of both anticipated and unanticipated changes suggesting that standard (structured VAR) suffer from informational insufficiency. Ricco (2015) indicates that wrongly expected fiscal shocks produce contractionary effect on the economy while expected and the unexpected fiscal shocks produce elicit expansionary effects. Forni and Gambetti (2015) have criticized VAR as tool of analysis for the fiscal shocks citing inconclusiveness and not containing enough information. Forni and Gambetti (2015) challenged that view with a one-year primary data and claim that "fiscal foresight" is a medium run phenomenon. This is due to the result of prediction which shows that in this quarter, government spending is better than GDP and consumption, but 1-quarter ahead of government spending is predicted worse than GDP. Hence it's possible to say that shocks are of two types anticipated like news or foresight shocks which have a slow effect on consumption but does affect expectation, and the other type is unanticipated shocks "surprise shocks" which affect spending on impact and only observed when consumer see realized spending, the latter type is principally in line with the traditional VAR system. On the fiscal shocks as well, the standard route in VAR analysis is computing it from estimated non-linear impulse responses which are in turn derived as conditional forecasts at each period of time according to Afonso et al. (2017).

The research in the area of government spending shocks is extensive, yet there is a specific disagreements in economics society about the effects of government spending shocks on consumption, VAR analysis in particular supports the view that increases in spending leads to a depreciation in of the real domestic currency provided the regime is in flexible exchange rate, this is proven so far with US Data (Perotti, 2007) and it opposes the standard theory of spending should appreciate the currency not the other way around. The two schools of thoughts in this regard are the standard Keynesian model and the Neoclassical model. Since The Keynesian theory which is widely acceptable has been challenged by the Neoclassical model in various occasions, and it has empirically been proven with US data that private consumption and output have a negative relationship with government spending in what is commonly referred to as the Neoclassical approach to fiscal policy, it is the left to decide whether shocks can play a role in the area.

Fiscal shocks to Romanian data using SVAR Model by Boiciuca (2015) maintained that Cholesky decomposition of variance-covariance matrix of VAR residuals is better at capturing structural shocks. This study recorded a rising positive real output response throughout the period to one standard deviation government expenditure shock and a positive sharply increasing response to government revenues until period 3 then intensity decline in period four then rise again and maintain average positive response to the rest of periods. Government revenue shocks also has real output positive rising response to one standard deviation unit shock while government expenditure rises sharply in the first period then maintain a positive response until the last period. Comparing this result with fiscal multipliers for developed economies, dynamic of the endogenous variables is consistent with the economic theory. 
Ambler et al. (2017) use Neoclassical model to study the claim of crowding out ${ }^{2}$ effect in RBC, considered public consumption and public investment in addition to exogenous variables like technology and preferences, concluded that innovation do crowd in private consumption. They claimed that impulse response function in the VAR reproduce the same pattern in the empirical literature, such empirical results may be explained and understood in support to the neoclassical model, especially that it cements the relationship movement between public spending and real wage.

Khanfir (2016) attempted to add more value to Keynesian literature in regard to the non-linear effect of fiscal changes to consumption. He considered interest rates a credible channel through which fiscal policy may influence output, high level of debt on government bonds will impose premium on interest rates to account for inflation and default risk, since private demand is sensitive to the real interest rates, and if the reduction in interest paid on government bonds decreases the real interest rate charged to consumers and businesses, such reduction can raise the financial wealth and boost consumption and investment. Changes in interest rates and household wealth justify the Keynesian theory on the effect of fiscal contraction.

Blanchard and Perotti (2002) is the study that has been widely cited in regard to the identification of shocks issue. (Blanchard \& Perotti, 2002)) calculate the elasticity by calculating the responsiveness of specific tax components to output fluctuations. They argue that there is no direct reaction of government spending components and changes in economic conditions, however the reaction of revenues to innovations in output changes the economic condition. There is a number of studies that regards identifying policy shocks as using sign restrictions on impulse response (Uhlig, 2005; Fuast, 1998; Mountford and Uhligb, 2009) believed that fiscal policy shocks may not be possible to identify without restricting the impulse responses of fiscal variables and to be treated in independent manner from monetary and fiscal shocks.

Lastly, arguing against the neoclassical model, Ramey and Shapiro (1998) claim that since labor is not feasibly mobile across different sectors of the economy other factors of production should be costly for relocation as well and in order to understand the aggregate effect of government spending one must understand the shifts in demand across sectors of the economy, and therefore the effect of government spending is sector-specific. Theoretically, considering permanent spending financed by non-distortionary tax regime, where marginal utility of private consumption is not changed; the increase in government spending creates a negative wealth effect for the individual consumer. If both goods and entertainment are normal goods the consumer would normal decrease his or her consumption and increasing labor supply which would in turn lower the real wage. Ramey and Shapiro (1998) also consider the composition of government spending like transfer programs are directed to very narrow sectors, therefore variations in spending on those programs can reflect different angel and shifts of demand for the output of key industries. It is evident in fiscal policy Neoclassical growth models (Chamley, 1986; Judd, 1985) the role of fiscal policy is detrimental to the level of output rather than the long-run growth rate, because the latter is driver by the exogenous factors of population growth and technology advancement, and its considered in that literature as a path to a steady economic growth, others suggested endogenous growth models as in Barro (1990) and others to determine the mechanism by which level of output and steady growth may be maintained. Endogenous growth models study is extended here, they rank elements of the government

\footnotetext{
2 crowding out effect refers to what occurs when increased government involvement in a sector of the market economy substantially affects the rest of the market, either on the supply or demand side of the market.

Copyright $\odot$ GLOBAL ACADEMIC EXCELLENCE (M) SDN BHD - All rights reserved
} 
budget into one of four categories; distortionary taxes, non-distortionary taxes, productive or non-productive expenditures. Distortionary taxes are the line of taxations that influence investment decisions directly hence affect the steady growth, non-distortionary line of taxation doesn't affect saving/investment due to the nature of utility function hence growth is left unhindered.

\section{Methodology}

Government expenditure has two main components, one of which is government final public consumption which in turn maybe broken into two; expenditures for collective consumption (defence, justice, etc.) which benefit society as a whole or large segments of it, they are often known as public goods, the second is government final private expenditure which is directed to serve individuals in specific fields; (healthcare, housing development, educational establishments, etc) such expenditure is incurred by the government on behalf of individuals, this category of expenditure by government is equal to social transfers in kind from government to households and so include expenditures by government on market goods and services provided to households, final consumption of government can be understood as the difference between government output and payments made for goods and services produced by government and the relevant output that is used for fixed capital formation.

On similar approach, discussing the impact of higher education public expenditure on income per capita the study of Ifa and Guetat (2018) inspired by (Schultz, 1961) suggesting that the education levels of individuals are critical factor using endogenous growth and concluding that there's a positive relationship between public expenditure on education and income using inflation to control variable, therefore we use this theory to test in Malaysian context using ARDL approach.

ARDL is a specification for the short run integrated variables in the pursuit of understanding the short run relationship between income per capita and fiscal spending change and One of the advantages of using ARDL is the fact it's an efficient tool of estimation for small size models and obtain unbiased of the long run relationship estimates, ARDL model treat independent variable as exogenous and the dependent variable as endogenous and it appears generally this way;

$y_{t}=a_{i}+\sum_{i=0}^{n} p \delta_{i} Y_{t-i}+\sum_{i=0}^{n} q \beta_{i} X_{t-i}+\varepsilon_{i t}$

Where $\mathrm{Y}$ is the vector, and the variables in $\mathrm{X}$ are allowed to be $\mathrm{I}(0)$ or $\mathrm{I}(1)$ or cointegrated $\delta$ and $\beta$ are coefficients, $\mathrm{a}$ is constant, $\mathrm{p}$ are optimal lag order for the dependent variable and $\mathrm{q}$ is the optimal lag order for the independent variables, $\mathrm{i}=1, \ldots, \mathrm{k}$, and $\varepsilon_{i t}$ is the vector of the error terms. According to the Granger representation theorem, if two variables are cointegrated, the relationship between two underpinning series can be expressed as error correction model ECM. Therefore, we use the following model for the short run estimates:

$$
\Delta I n G D P C=a 0+\sum_{i=1}^{p} a 1 \Delta \operatorname{InGDPC} C_{t-j} \sum_{i-j}^{q} a 2 i \Delta \operatorname{InExp} \sin _{t-1}+\sum_{i=j}^{q} a 3 i \operatorname{In} E d u_{t-1}+E C T+e
$$

$p=$ number of lags for the $\mathrm{dv}, \mathrm{q}=$ number of lags for variable/residual series is used as ECT, GDPC (constant 2010 US\$) is GDP per capita. EXP is government final consumption expenditure. EDU is general government expenditure on education (current, capital, and transfers). Education expenditure refers to the current operating expenditures in education, 
including wages and salaries and excluding capital investments in buildings and equipment. INF is inflation, used here as a control variable.

\section{Results and Discussions}

Descriptive analysis of the data is shown in Table 1 . The mean value is slightly greater than median value for data lnEDU and INF, meaning that these data are slightly skewed to the right. The standard deviation for lnGDPC, lnEXP01, lnEDU and INF is small, meaning that all the data are tightly clustered around the mean. The value of Jarque-Bera is greater than 0.05 for all the variables, meaning that all variables are normally distributed.

Table 1: Descriptive Analysis of The Data

\begin{tabular}{|c|c|c|c|c|}
\hline & InGDPC & InEXP01 & InEDU & INF \\
\hline Mean & 8.702298 & 4.118119 & 22.04863 & 3.050714 \\
\hline Median & 8.793309 & 4.114779 & 21.92250 & 2.813201 \\
\hline Maximum & 9.249369 & 4.291442 & 23.71379 & 9.700000 \\
\hline Minimum & 8.106816 & 3.938267 & 20.84825 & 0.290008 \\
\hline Std. Dev. & 0.362002 & 0.091172 & 0.844531 & 1.946792 \\
\hline Skewness & -0.213607 & 0.036383 & 0.518574 & 1.207891 \\
\hline Kurtosis & 1.664565 & 2.206534 & 2.181025 & 5.226261 \\
\hline Jarque-Bera & 2.866935 & 0.925870 & 2.546828 & 15.73869 \\
\hline Probability & 0.238481 & 0.629433 & 0.279875 & 0.000382 \\
\hline Sum & 304.5804 & 144.1341 & 771.7019 & 106.7750 \\
\hline Sum Sq. Dev. & 4.455548 & 0.282619 & 24.24990 & 128.8599 \\
\hline Observations & 35 & 35 & 35 & 35 \\
\hline
\end{tabular}

Unit roots test is the standard test for time-series data to indicates the presence of stationarity. Unit root hypothesis helps to identify some features of the underlying data-generating process of a series. The first is assessing the order of integration which is crucial for setting up an econometric model and to inference. The second motive is that economic theory suggests that certain variables should be integrated, a random walk or a martingale process. If these variables are I(1), then cointegration techniques can be used to model these long-run relations, maximum lag used is lag 4 according to Akaike Information criterion.

Table 2: Unit Root Test for The Variables

\begin{tabular}{|l|l|l|l|l|}
\hline \multirow{2}{*}{ Variable/status } & \multicolumn{2}{|l|}{ Level } & First difference \\
\cline { 2 - 5 } & Without trend & With trend & Without trend & With trend \\
\hline InGDPC & -0.670823 & -1.693412 & -4.811492 & -4.743523 \\
\hline InExp & -1.492894 & -0.813216 & -5.438934 & -5.966489 \\
\hline InEdu & 0.547656 & -1.759805 & -5.709407 & -5.912828 \\
\hline Inf & $-3.517598^{*}$ & -3.501731 & -8.559260 & -8.811773 \\
\hline
\end{tabular}

We can infer from the cointegrating equation, that the indicator for Government consumption expenditure has a negative relationship with income per capita in the long run ceteris paribus, and that the indicator for education expenditure has a positive relationship with income per capita in the long run ceteris paribus, while INF has a positive relationship with income per capita in the long run. The and short run (SR) and long run (LR) relationship of the series of the model with GDPC being the main variables is expressed in Table 3. 
Table 3: Specifying VECM at (p-1) Lag Results

\begin{tabular}{|c|c|}
\hline $\begin{array}{l}\text { Long } \quad \text { Run } \\
\text { expression at lag } 4\end{array}$ & $\begin{aligned} E C T_{t-1}=1.000000 \operatorname{InGDPC}+1.354555 \operatorname{In} E X P_{t-1} \\
\quad-0.346653 \operatorname{InED} U_{t-1}-0.008603 \operatorname{INF}_{t-1} \\
-6.611064\end{aligned}$ \\
\hline $\begin{array}{l}\text { Short Run } \\
\text { Expression at lag } 4\end{array}$ & $\begin{aligned} \operatorname{InGDPC}_{t}= & -0.060292 E C T_{t}+0.012694 \Delta \operatorname{InEXP_{t-1}} \\
& -0.062290 \Delta \operatorname{InED} U_{t-1}+0.000460 I N F_{t-1} \\
& +0.042000\end{aligned}$ \\
\hline
\end{tabular}

The results show that the rate of convergence of the series back to equilibrium is $6 \%$, meaning to say that that $6 \%$ of disequilibrium is being corrected every year in the series at hand. In the short run, $1 \%$ increase in government consumption will result in $1.2 \%$ negative change in income per capita indicator, $1 \%$ increase in government expenditure in education will result in $6 \%$ positive change in income per capita indicator, and $1 \%$ increase in inflation indicator will result in $0.046 \%$ positive change in income per capita indicator. The following diagnostic results were obtained from the VEC model; Jarque-Bera overall $(\mathrm{P}=0.0003)$ : which indicates the series of the model are not normally distributed in the variable of interest (dependent variable), normally distributed for the regressors. Residual Hetero (No cross terms): $(\mathrm{P}=$ $0.6430)$ which indicates that the model doesn't suffer from heteroscedasticity problem. Serial correlation LM test at lag 4: $(\mathrm{P}=0.7399)$ : Indicating that residuals are not serially correlated. Stability according to CUSUM.

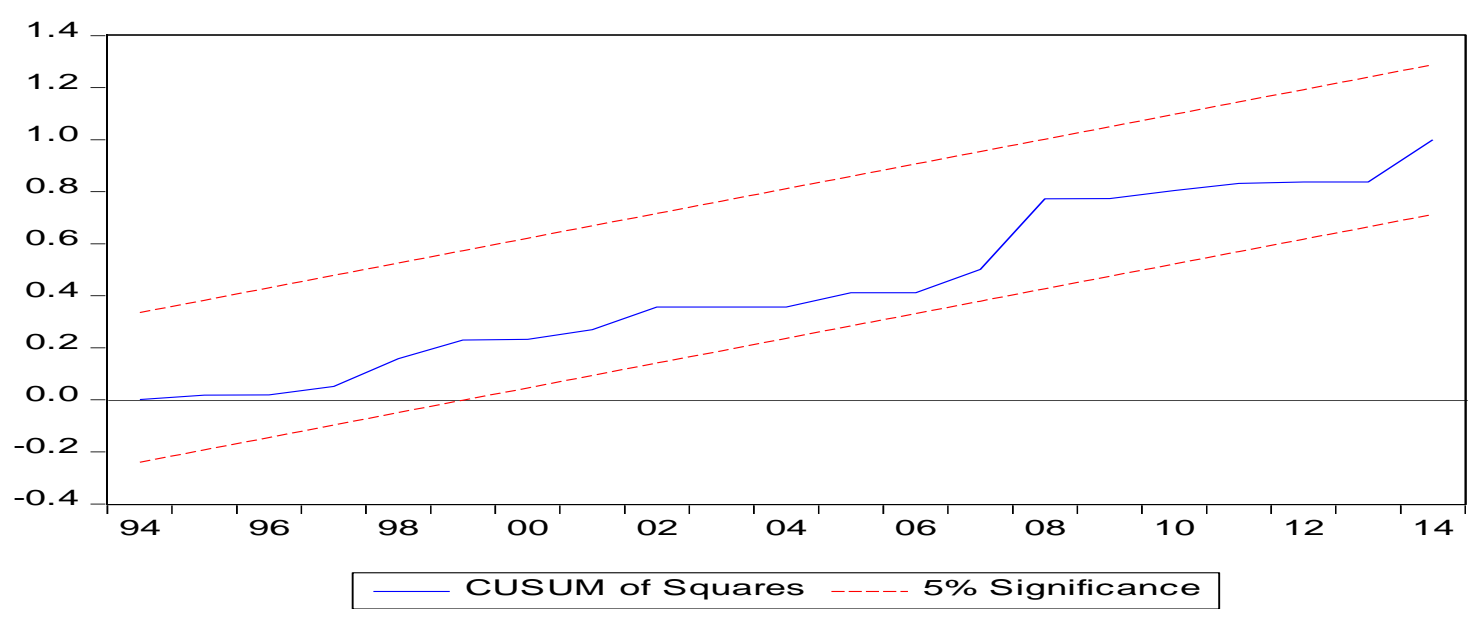

Figure 1: CUSUM Square

In macroeconomic research, many variables are interlinked with causality and that can be understood from various angels, $\mathrm{X}$ causes $\mathrm{Y}$, It may mean that $\mathrm{X}$ leads to $\mathrm{Y}, \mathrm{X}$ is the only cause of $\mathrm{Y}, \mathrm{X}$ is one the probable causes of $\mathrm{Y}, \mathrm{X}$ determines $\mathrm{Y}$, the occurrence of $\mathrm{X}$ makes the occurrence of $\mathrm{Y}$ more likely, $\mathrm{X}$ is the probabilistic cause of $\mathrm{Y}$, although regression explain dependence of one variable on another it doesn't imply causality, and the fact that time series variables are in a relationship it doesn't mean they cause one another. Hence we'll precede with following causality test tools;

I. Granger/Wald causality test on lagged explanatory variables: that is where Ho: Lagged coefficient(s) = 0, H1: is that they are not $($ Chi Sqr. <0.05) 
II. Pairwise Granger on the direction of causality: That is where Ho: No granger-causality, H1: There is granger causality. ( $F$-statistic $<0.05)$

Table 4: The results of Granger/Wald causality and Pairwise Granger

\begin{tabular}{|c|c|}
\hline $\begin{array}{l}\text { Long Run Causal } \\
\text { Effect }\end{array}$ & $\begin{array}{l}\mathrm{D} \text { (InGDPC) as variable of interest: } \\
\text { Adjustment parameter indicates that model converge in the long run: } \\
\text { Coefficient }=-0.009531 \\
\mathrm{P}=0.862 \text { (the adjustment coefficient significant at } 10 \% \\
\mathrm{D} \text { (InEXP) as a variable of interest: } \\
\text { Adjustment parameter indicate that model converge in the long run: } \\
\text { Coefficient = -0.003266 } \\
\mathrm{P}=0.9519 \text { (the adjustment coefficient is significant at } 10 \% \\
\mathrm{D} \text { (InEDU) as a variable of interest: } \\
\text { Adjustment parameter is not significant indicating that system doesn't } \\
\text { converge in the long run } \\
\text { (Inf) as a variable of interest: } \\
\text { Adjustment parameter is not significant indicating that it doesn't } \\
\text { converge in the long run }\end{array}$ \\
\hline $\begin{array}{l}\text { Short run causal } \\
\text { effect }\end{array}$ & $\begin{array}{l}\text { In (GPC) is the variable of interest: } \\
\text { InEXP: is significant at } 10 \%(p=0.8782) \\
\text { InEDU: is significant at } 10 \%(p=0.9833) \\
\text { INF: is significant at } 10 \%(p=0.8628)\end{array}$ \\
\hline
\end{tabular}

For the long run causality; we can infer from the result that EXP only has a long run causal effect on GDPC, while EDU, INF doesn't have or other factors unaccounted for influenced the causality. For the short run causality; we can infer from the result that that EXP, EDU, INF has a unidirectional short run causal effect on GDPC, but the opposite is not true.

\section{Conclusion}

This study was conducted to compliment an extensive literature on fiscal policy changes in Malaysia from the angel of GDP per capita, considering that very few papers addressed fiscal changes direct impact on income. For the purpose of that, this study utilized the Auto regressive distributed lag (ARDL) function because it is very insightful tool to provide information on the long run relationships due to the data stationarity of different orders. In this case, long run relationships cannot be statistically examined by Johansson Contegration test. The findings indicate a unidirectional long run causality from government expenditure to income which is against the findings of Cheong (2001) who employed Johansson test and noted the causality in the opposite direction using a set of annual data from 1960-1998. However, without accounts for structural breaks, this study supports the argument that increasing government spending invites negative wealth effects which is in line with (RBC) model. VEC model, results indicate that negative effect of increased government spending is consistent from the short run to the long run. 


\section{References}

Afonso, A., Baxa, J., \& Slavík, M. (2017). Fiscal developments and financial stress: a threshold VAR analysis. Empirical Economics, 54(2), 395-423.

Ambler, S., Bouakez, H., \& Cardia, E. (2017). Does the Crowding-In Effect of Public Spending on Private Consumption Undermine Neoclassical Models? Research in Economics.

Barro, R. J. (1990). Government Spending in a Simple Model of Endogeneous Growth. Journal of Political Economy, 98(5).

Baxter, M., \& King, R. G. (1993). Fiscal Policy in General Equilibrium. The American Economic Review, 83(3), 315-334.

Blanchard, O., \& Perotti, R. (2002). An empirical characterization of the dynamic effects of changes in Government spending and Taxes on output. The Quarterly Journal of Economics.

Boiciuca, I. (2015). The effects of fiscal policy shocks in Romania. A SVAR approach. Procedia Economics and Finance, 32, 1131-1139.

Burnside, C., Eichenbaum, M., \& Fisher, J. D. (2004). Fiscal shocks and their consequences. Journal of Economic Theory, 115, 89-117.

Chamley, C. (1986). Optimal Taxation of Capital Income in General Equilibrium with Infinite Lives. Econometrica, 54(3), 607-622.

Cheong, T. T. (2001). Testing the relationship between government expenditure and national income in Malaysia . Analisis, 8(1-2), 37-51.

Fatas, A., \& Mihov, I. (1998). The effect of fiscal policy on consumption and employment: Theory and evidence. Toulouse, France: ECARES (Center for financial studies).

Forni, M., \& Gambetti, L. (2015). Government spending shocks in open economy VARsMario Forni, Luca Gambetti. Journal of International Economics.

Fuast, J. (1998). The Robustness of Identified VAR conclusions about Money. CarnegieRochester Conference Series on Public Policy, 49.

Ibrahim, M. H. (2005). Sectoral Effects of Monetary Policy: Evidence from Malaysia. Asian Economic Journal, 19(1),.

Ifa, A., \& Guetat, I. (2018). Does public expenditure on education promote Tunisian and Moroccan GDP per capita? ARDL approach. The Journal of Finance and Data Science, 4, 234-246.

Jordi, G., López-Salido, J. D., \& Vallés, J. (2007). Understanding the effect of government spending on consumption . Journal of The European Economic Association , 5(1), 277.

Judd, K. L. (1985). Redistributive taxation in a simple perfect foresight model . Journal of Public Economics , 28, 59-83.

Khanfir, W. (2016). Threshold effect of fiscal policy on private consumption: Evidence from Tunisia . The Romanian Economic Journal, 18(59).

Landon, S., \& Smith, C. (2017). Does the design of a fiscal rule matter for welfare? Economic Modelling, 63, 226-237.

Matsuki, T. (2018). Per capita output convergence across Asian countries: Evidence from covariate unit root test with an endogenous structural break. Economic Modelling.

Mountford, A., \& Uhligb, H. (2009). What are the effects of fiscal policy shocks? Journal of Applied Econometrics, 24, 960-992.

Mumtaz, H., Sunder-Plassmann, L., \& Theophilopoulou, A. (2018). The State-Level Impact of Uncertainty Shocks. Journal of Money, Credit and Banking, 50(8).

Perotti, R. (2007). In Search of the Transmission Mechanism of Fiscal Policy. NBER Macro Annual, 22.

Pesaran, H., Shin, Y., \& Smith, R. (2001). Bounds testing approaches to the analysis of level relationships. Journal of Applied Econometrics . 
Ramey, V. A., \& Shapiro, M. D. (1998). Costly capital reallocation and the effects of government spending. Carnegie-Rochester Conference Series on Public Policy, 48, 145-194.

Ramey, V. (n.d.). Macroeconomic shocks and their propagation . In Handbook of Macroeconomics: Volume $2 A$ (p. 74). California : Elsevier B.V.

Ricco, G. (2015). A new identification of fiscal shocks based on information flow. European Central Bank.

Richard. K., Michael, F. B, \& Norman, G. (1999). Fiscal policy and growth: evidence from OECD countries, Journal of Public Economics.

Schultz, T. W. (1961). Investment in Human Capital. The American Economic Review, 51(1), $1-17$.

Sharma, R., \& Kautish, P. (2019). Aid-Growth Association and Role of Economic Policies: New Evidence from South and Southeast Asian countries. Global Business Review, $1(18)$.

Uhlig. (2005). What are the effects of monetary policy? Results from an agnostic identification procedure. Journal of Monetary Economics, 52(381-419).

Zeyneloglu, I. (2018). Fiscal policy effectiveness and the golden rule of public finance. Central Bank Review, 18, 85-93. 